\title{
FENOMENOLOGI NILAI SLAMETAN MASYARAKAT YOGYAKARTA DALAM PERSPEKTIF MAX SCHELER
}

\author{
Marista Christina Shally Kabelen \\ Program Studi Teknik Informatika, \\ Fakultas Teknik, Matematika dan IPA \\ Universitas Indraprasta PGRI \\ marista.kabelen@yahoo.com
}

\begin{abstract}
Abstrak
Kehidupan manusia tidak dapat dilepaskan dari nilai. Bagi masyarakat Yogyakarta, nilai selalu mengiringi setiap ritual dalam siklus kehidupan manusia. Salah satu bentuk ritual yang masih dilestarikan masyarakat Yogyakarta adalah slametan. Tujuan diadakan penelitian ini adalah untuk mengkaji nilai dalam slametan masyarakat Yogyakarta dalam perspektif Max Scheler. Penelitian ini menggunakan metode interpretasi melalui studi kepustakaan. Hasil penelitian ini adalah sebagai berikut; slametan masyarakat Yogyakarta adalah fenomena yang menekankan pengalaman intuitif terhadap pemahamannya atas Yang Mutlak. Dalam perpektif Max Scheler slametan sebagai ritual memiliki makna simbol dalam sesajinya mengandung empat gugus nilai, yakni: nilai kenikmatan, nilai vitalitas, nilai spiritual, dan nilai kesucian.
\end{abstract}

Kata kunci: ritual; sesaji; slametan; fenomenologi; nilai

\section{Phenomenology of Value in Yogyakarta's Societ Slametan in Max Scheler's Perspective}

\begin{abstract}
Human's life can not be detached from value. For Yogyakarta's society, value always accompanied each rituals in human's life cycle. One form of ritual still preserved by Yogyakarta's society is slametan. The purpose of this research is to assess the value in slametan of Yogyakarta's society in Max Scheler's perspective. This research using interpretation method through literature review. The outcome of this research are; The Yogyakarta's society's slametan is a phenomena that stressed the intuitive experiences on its comprehension of The Absolute. In Max Scheler's perspective, slametan as ritual has symbol meaning in its sesaji (offerings) consists four values, which are: pleasure value, vitality value, spiritual value, and holiness value.
\end{abstract}

Keyword: ritual; sesaji; slametan; phenomenology; value 


\section{PENDAHULUAN}

Manusia merupakan makhluk sosial yang tidak dapat hidup sendiri, mereka membutuhkan manusia lain untuk membentuk dan mengembangkan diri. Dalam proses pembentukan dan pengembangan diri, manusia tidak dapat dilepaskan dari nilai, karena nilai merupakan sebuah daya yang mendorong tindakan manusia dan memberinya makna. Nilai itulah yang membantu manusia mengarahkan hidupnya, Max Scheler mengungkapkan bahwa nilai adalah hal yang dituju manusia, jika ada yang mengejar kenikmatan, maka hal itu bukan demi kepuasan perasaan saja, melainkan karena kenikmatan yang dipandang sebagai suatu nilai.

Nilai selalu mengiringi setiap siklus dalam kehidupan manusia. Siklus kehidupan manusia yang selalu berkelanjutan adalah kehidupan di dalam rahim, kehidupan di dunia, dan kehidupan setelah kematian. Setiap siklus terdapat proses-proses penting yang selalu ditandai dan dimaknai oleh manusia. Salah satu upaya untuk menandai setiap peristiwa penting dalam siklus kehidupannya, manusia mengadakan ritual dengan memberikan persembahan yang disebut dengan sesaji. Ritual dan sesaji tidak dapat dipisahkan satu sama lain, karena sesaji di dalam ritual merupakan bagian pokok yang harus dijalankan.

Salah satu ritual yang menggunakan sesaji yang dilakukan dalam siklus kehidupan di dunia adalah slametan yang merupakan salah satu wujud budaya yang masih dipertahankan oleh beberapa masyarakat di suku Jawa, sehingga penulis ingin mengulasnya dalam tulisan ini. Slametan merupakan sebuah fenomena, sesuatu yang tampak. Slametan merupakan wujud konkret dari pengalaman spiritual manusia. Slametan merupakan bentuk ritual yang tidak bisa dipisahkan dengan sesaji. Slametan yang terdapat pada masyarakat suku Jawa memiliki keberagaman, sehingga dalam tulisan ini hanya akan dibahas slametan secara umum, inti dari slametan yang dijalankan masyarakat Yogyakarta.

Slametan masyarakat Yogyakarta yang merupakan salah satu kegiatan persembahan yang paling sering dilakukan dalam siklus kehidupan manusia, ini lebih menarik perhatian penulis untuk dikaji nilai-nilainya. Alasan mengapa harus Yogyakarta karena ada ketertarikan penulis pada Yogyakarta serta keterikatan penulis karena tumbuh dan dididik dengan tradisi Yogyakarta.

Slametan bisa dikatakan sebagai upaya yang dilakukan oleh masyarakat Yogyakarta untuk membuang kemalangan atau kesialannya dan mendapatkan keselamatan. Wahyana Giri menuliskan dalam bukunya berjudul 'Sajen dan Ritual Orang Jawa' (Narasi, 2010) bahwa dengan menjalankan laku spiritual, manusia ingin menjauh dari kemalangan atau kesialan sehingga keberuntungan bisa mendekat. (Wahyana, 2010: 7)

Masyarakat Indonesia masih percaya nasib ditentukan oleh usaha, doa dan faktor $\mathrm{X}$. Wahyana menyatakan faktor X menentukan keberuntungan seseorang atau kesialannya. Sehingga adanya sesaji atau semah adalah untuk meminimalisir faktor kesialan dan memaksimalkan faktor keberuntungan. (Wahyana, 2010: 8)

Faktor $\mathrm{X}$ yang disebutkan menandakan tidak adanya kuasa manusia atas kasualitas dari usaha yang mereka lakukan. Sementara doa sebagai bentuk struktural masyarakat Jawa yang telah ada sejak lama. Faktor $\mathrm{X}$ demikian besar mempengaruhi munculnya slametan dalam masyarakat Jawa sehingga terkonstruksi eksistensi transenden yang diyakini memiliki kapabilitas super. Eksistensi transenden yang dimaksud dikenal luas dengan nama Tuhan.

Oleh karena itu, dalam tulisan ini hendak membedah nilai - nilai yang hendak disampaikan oleh slametan yang terdapat dalam masyarakat Yogyakarta 
dengan pemikiran Max Scheler. Nilainilai dalam sesaji slametan masyarakat Yogyakarta akan dianalisis dengan menggunakan konsep fenomenologi nilai Max Scheler. Karena sesaji slametan pada masyarakat Yogyakarta merupakan implementasi dari pengalaman intuitif yang melibatkan emosi untuk menghadirkan nilai. Karena penulis memahami fenomena slametan tentunya tidak terlepas pada kehadiran nilai sebagai pengalaman pragmatis. Slametan diharapkan mampu memberikan kemudahan secara spiritual dalam menjalankan kehidupan untuk memenuhi kebutuhan yang bersifat materiil. Sehingga penulis merumuskan beberapa masalah yang akan menjadi wilayah kajian dalam tulisan ilmiah ini. Berikut adalah sejumlah rumusan masalah yang dihimpun: (1) Apakah slametan dalam Masyarakat Yogyakarta merupakan fenomena dalam perspektif Max Scheler? (2) Bagaimana nilai a priori material dalam slametan masyarakat Yogyakarta dalam perspektif Max Scheler? (3) Bagaimana kajian konsep nilai Max Scheler terhadap simbol sesaji dalam slametan masyarakat Yogyakarta? Dengan rumusan masalah tersebut, diharapkan dapat membantu mencapai tujuan yang diharapkan, yakni menjelaskan secara rinci slametan dalam masyarakat Yogyakarta sebagai bentuk fenomena dalam kaca mata Max Scheler, memberikan pemahaman konsep nilai $a$ priori material Max Scheler terhadap slametan masyarakat Yogyakarta, menganalisa konsep nilai Max Scheler dalam simbol sesaji slametan masyarakat Yogyakarta.

\section{Tinjauan Pustaka}

Fenomenologi Nilai Max Scheler

Fenomenologi berasal dari bahasa Yunani dengan asal suku kata phenomenon. Fenomenologi berasal dari bahasa Yunani yakni phenomenon, yang berarti sesuatu yang tampak atau disebut juga dengan gejala. Fenomenologi merupakan suatu aliran yang mempelajari tentang fenomena atau segala sesuatu yang menampakkan diri. Dalam fenomenologi, sebuah fenomena tidak harus diamati dengan indera, melainkan dapat juga dilihat melalui pengalaman rohani. Karena fenomenologi memandang suatu fenomena sebagai sesuatu yang menampakkan diri dalam dirinya sendiri.

Fenomenologi Max Scheler memiliki tiga sifat positif seperti berikut, erleben yaitu pengalaman intuitif terhadap hal sebagaimana adanya, dan sekaligus bertujuan menyelami hal yang diberikan itu sendiri. Kedua, perhatian diarahkan pada "apanya" (esensi) dan menunda memperhatikan pertanyaan tentang "bagaimana"nya. Dan yang ketiga, perhatian diarahkan pada hal-hal yang berada secara a priori, serta diarahkan pada hubungan esensial atau hakiki yang berada di natara hal yang bersangkutan. Melalui tiga sifat tersebut, pengalaman fenomenologi melengkapi faktanya sendiri secara langsung, tanpa simbol atau tanda, pengalaman ini merupakan pengalaman asimbolik.

Pengalaman fenomenologi merupakan 'murni dan langsung', sedangkan pengalaman inderawi adalah 'dikondisikan dan dipengaruhi oleh struktur organis partikular dari pelaku'. Pengalaman fenomenologi yang disebut 'murni dan langsung' memiliki arti sebagai sebuah pengalaman yang termanifestasikan secara langsung dan tidak terikat atau mengasosiasikan sesuatu (murni). Pengalaman inderawi yang disebut sebagai 'dikondisikan dan dipengaruhi oleh struktur organis partikular dari pelaku' berarti bahwa pengalaman tersebut dikonstruksi berdasarkan aturan tertentu atau diintepretasikan untuk mencapai tujuan tertentu. Secara mendalam, pengalaman fenomenologis adalah 
pengalaman yang mengasosiasikan sebuah makna yang independen, sedangkan pengalaman inderawi tidak independen karena adanya intervensi subjektif yang memiliki tujuan dari pelaku atau pengindera. (Meyer Herbert, 1987: 21)

\section{Konsep Nilai Max Scheler}

Menurut Scheler, nilai merupakan kualitas yang tidak bergantung pada benda, namun benda adalah sesuatu yang bernilai. Independensi yang dimaksud mencakup setiap bentuk empiris, karena nilai adalah kualitas a priori. Independensi tidak hanya mengacu pada objek yang ada di dunia, namun juga reaksi manusia terhadap benda dan nilai.

Scheler meyakini, dalam tulisannya Formalism in Ethics and Nonformal Ethics of Values, bahwa sekalipun pembunuhan tak pernah 'dinilai' jahat, hal tersebut akan terus menerus menjadi jahat. Meskipun yang baik tidak pernah 'dinilai' baik, hal tersebut akan tetap menjadi baik. Pada umumnya, apakah ego memiliki nilai atau mengalaminya, sebagaimana eksistensi objek atau alam tidak mengasumsikan sebuah ego, kurang lebih demikianlah yang diimplikasikan oleh hakikat nilai. Hal ini menunjukkan loyalitas keyakinan Scheler, benda dan tujuan tidak memiliki acuan nilai terhadap esensinya. (Frondizi, Risieri, 2007: 124)

Hal tersebut dijelaskan Scheler bahwa nilai tidak berada pada dirinya sendiri, melainkan selalu tampak pada manusia sebagai yang ada pada pembawa nilai, atau objek bernilai. Pembawa nilai tersebut adalah objek yang nyata dan dapat diketahui melalui indera, nilainya sendiri tidak tampak pada indera manusia. Oleh karena itu, perlulah kita mencoba mengkaji nilai dan hubungannya dengan manusia, sebagai upaya memahami nilai.

Nilai merupakan jenis objek yang tidak dapat dimasuki oleh rasio, hal ini dijelaskan oleh Scheler sebagai yang menyatakan diri pada manusia melalui persepsi sentimental, dalam preferensi, cinta, dan benci. Scheler menerapkan peran fenomenologis atas kehidupan emosional, yang memungkinkan baginya untuk memberikan berbagai tingkatan dunia emosional yang tidak bisa dibedakan dengan jelas.

Hal ini terkait pada penjelasan Scheler yang membedakan antara perasaan intensional dengan keadaan perasaan sensitif. Keadaan perasaan sensitif mengacu pada pengalaman murni dari keadaan, sedangkan perasaan intensional berkaitan dengan pemahamannya, contohnya ialah rasa sakit yang diderita seseorang berbeda dengan orang yang melihatnya. Secara afektif, hal tersebut tidak memiliki unsur intensional, karena acuannya merupakan perantara, yakni setelah perasaan diwujudkan. Acuan mungkin berupa kausalitas, sehingga hubungan ditetapkan dengan menggunakan pikiran. Perasaan intensional memiliki acuan langsung pada objek, dan di dalam perasaan intensionallah nilai menyatakan diri. Perasaan sentimental tidak menyatu dengan objek yang berada di luar, atau dengan menggunakan citra, objek juga tidak tampak sebagai tanda dari sesuatu yang tersembunyi di belakangnya. (Frondizi, Risieri, 2007: 125-126)

Manusia menangkap nilai dengan menggunakan pengalaman emosional tentang persepsi sentimental. Manusia bukanlah penerima pasif impresi dari benda atau lingkungan disekitar manusia itu sendiri. Hubungan subjek-objek merupakan gerakan dinamis antara manusia dengan benda atau lingkungan di sekitarnya yang menghasilkan isi pengalaman praktis. Melalui pandangan manusia yang bersifat alami, objek nyata tidak diberikan kepada manusia sebagai barang atau benda murni, melainkan sebagai barang yang telah memiliki nilai. A priori mengenai adanya nilai pada barang atau 
benda murni tersebut didasarkan pada tindakan kesadaran yang berlangsung secara intensional. Hal ini dijelaskan oleh Max Scheler untuk mendasari prinsip intensionalitas tersebut, dengan hal tersebut menunjuk nilai sebagai fenomena dasar yang tidak dapat direduksikan atau dikembalikan pada fenomena lainnya, missalnya hasil pemahaman rasional inderawi, dan fenomena dasar ini ditemukan dan dipahami melalui intuisi perasaan terhadap nilai tersebut. Hal ini menandakan bahwa nilai tersedia bagi perasaan intensional secara mendalam, sebagai hubungan intensional antara perasaan dengan nilai yang bersangkutan.

Max Scheler berpendapat bahwa pikiran itu buta terhadap nilai, karena nilai tidak dirasakan dengan pikiran, melainkan melalui intuisi emosional. Intuisi memiliki kemampuan yang tepat dalam menangkap dan merasakan nilai, serta tanpa membutuhkan dasar pengalaman inderawi terlebih dahulu terhadap objek bernilai yang terkait. Memahami nilai, manusia dapat merasakan yang sebenarnya, yang diberikan pada manusia secara jelas dan terang, bahkan tanpa menggunakan pembawa nilai bersangkutan. (Paulus Wahana, 2004: 70-71).

Terdapat suatu jenis pengalaman yang objeknya sama sekali tidak dapat diterima oleh pemahaman akal, jenis pengalaman ini memberikan pada kita objek-objek yang sungguh objektif yang diatur dalam susunan yang tetap, yaitu pengalaman akan nilai-nilai beserta ketersusunan yang bersifat hierarki. Keteraturan dan hukum yang termuat dalam pengalaman ini bersifat pasti dan jelas, seperti dalam logika.

Pemahaman tentang nilai pada umumnya merupakan proses historis yang dinamis, bahkan berlaku pula untuk pemahaman tentang nilai dari person lainnya. Manusia dan Tuhan tidak pernah dapat terungkap sebagai objek, karena person tidak dapat diobjektivikasikan.
Hanya melalui proses partisipasi cinta terhadap tindakan yang lain, manusia dapat memahami dan mengetahui dirinya. Pribadi lain hanya dapat terungkap oleh manusia dengan berpartisipasi pada tindakannya, dan secara kognitif dengan pemahaman serta menghayati kehidupannya, atau secara moral mengikuti jejaknya. Keseluruhan dari hal ini ditekankan oleh Max Scheler, dengan menyatakan bahwa person merupakan nilai tertinggi, sehingga cara untuk memahami dan mengetahui person lain tidak hanya merupakan suatu paradigma pengungkapan untuk memahami semua nilai, tetapi juga merupakan langkah untuk dapat menanyakan terus-menerus dan mencoba menyelami kenyataan nilai yang tak terbatas. Selanjutnya, realitas nilai yang bersifat abadi dan tetap telah menyingkap diri pada setiap zaman dan pada setiap kelompok sosial hanya dalam perspektif yang terikat keterbatasan waktu.

Upaya manusia secara universal untuk nilai memancarkan cahaya pencaharian yang tidak terbatas atas keseluruhan nilai yang luas, menemukan keanekaragaman perspektif tak terbatas terhadap nilai-nilai yang berbeda. Melalui pemahaman lain, keseberagaman dan perbedaan berbagai kebenaran semuanya bersumber dari persepsi atas satu kenyataan atau realitas dari berbagai ide, serta ketersusunan nilai yang satu. Seluruh kebenaran dan berbagai nilai yang diterima oleh kelompok atau zaman tertentu yang berbeda merupakan aspekaspek terbatas dari yang satu, berbagai refleksi dan pernyataan dari suatu realitas kebenaran yang secara ontologis tak terpahami secara tuntas merupakan realitas yang terletak di luar dan mengatasi kerangka ruang dan waktu. (Paulus Wahana, 2004: 71)

Hal ini merupakan pemahaman yang diberikan oleh Max Scheler yang berarti bahwa nilai, apapun usaha pemahaman yang dilakukan dan apapun 
metodenya dalam mencapai pemahaman tersebut, memiliki sebuah pemaknaan yang tidak terlepas oleh ruang dan waktu, akan tetapi pemahaman yang didasari oleh intuisi dan intensionalitas absolut tidak tereduksi atau mengalami transformasi yang disebabkan oleh ruang dan waktu.

Intuisi dan intensionalitas yang absolut tersebut dijelaskan lebih mendalam sebagai bentuk manusia yang belum memikirkan dan menghendaki sesuatu, yaitu sebagai mencinta. Mencinta merupakan aktivitas yang berkaitan dengan hati manusia, yang merupakan keteraturan dari segala yang mungkin berhubungan dengan tindakan mencinta, yaitu nilai. Terkait hal ini, Max Scheler memberikan istilah ordo amoris, yaitu mikrokosmos dari dunia nilai, yang berarti sama dalam seluruh umat manusia. Hal tersebut disebabkan dalam diri setiap manusia telah menerima susunan nilai yang sama, meskipun setiap manusia juga memiliki mikrokosmos nilai khusus sesuai dengan perasaan masing-masing. Hati manusia merupakan tempat ordo amoris, sehingga mikrokosmos seluruh dunia nilai adalah objektif. Hati manusia merupakan suatu pasangan teratur dari dunia nilai. Kemudian Scheler, dalam tulisannya berjudul Ordo Amoris, menyatakan hati manusia yang secara moral baik pada dasarnya telah sesuai dengan hierarki nilai objektif. Dimensi emosi manusia dibentuk oleh 'ordo amoris'. Dapat dikatakan hati manusia merupakan papan sehat secara subjektif dari susunan objektif berbagai nilai. (Paulus Wahana, 2004: 73)

Istilah ordo amoris memiliki dua definisi, pertama definisi normatif dan kedua definisi deskriptif. Definisi normatif menjelaskan istilah tersebut dengan menyatakan bahwa ordo amoris menandakan susunan cinta yang benar secara objektif atau pasangan teratur dari hierarki nilai yang direfleksikan dalam hati manusia. Definisi deskriptif pun menjelaskan istilah ini sebagai sistem penilaian aktual serta preferensi nilai yang bekerja dalam kehidupan manusia individual. Hal ini berarti bahwa ordo amoris merupakan struktur dasar penyusunan moral pribadi dan merupakan dasar bagi munculnya seluruh tindakan individual dari kebiasaan moralnya, ordo amoris dari pemahaman Scheler berarti rumusan moral dasar yang menjadi acuan bagi kehidupan manusia dalam bidang moral.

\section{Hierarki Nilai Max Scheler}

Max Scheler membagi nilai ke dalam empat struktur nilai yang tersusun menjadi susunan hierarki nilai dari tingkat yang lebih tinggi menurun ke tingkat yang lebih rendah, yang bersifat $a$ priori. Hierarki ini tidak dapat dideduksikan secara empiris, tetapi terungkap melalui tindakan preferensi, yaitu melalui intuisi preferensi-evidensi. Hierarki nilai bersifat mutlak dan mengatasi segala perubahan historis, serta membangun suatu sistem acuan yang absolut dalam etika, yang merupakan dasar untuk mengukur dan menilai berbagai macam etos, dan segala perubahan moral dalam sejarah. Melalui keseluruhan realitas nilai, hanya terdapat satu susunan hierarki yang menyusun seluruh nilai yang memiliki posisinya sendiri. Artinya, nilai memiliki kedudukan lebih tinggi atau lebih rendah dibandingkan dengan yang lainnya. Susunan tersebut terdapat dalam inti setiap nilai, dan hal ini tidak hanya terdapat pada nilai yang diketahui saja, seperti pada perbedaan nilai baik dan buruk. Setiap nilai, baik yang diketahui maupun tidak, memiliki tempat tersendiri dalam hierarki nilai.

Berdasarkan pendekatan di atas, kemudian dapat dipahami bahwa suatu nilai lebih tinggi daripada yang lain dalam sebuah tindakan pemahaman 
khusus terhadap nilai, yaitu tindakan preferensi, sebuah pemahaman akan tingkat tinggi dan rendahnya suatu nilai. Seseorang tidak diperkenankan memperkirakan bahwa tingkatan suatu nilai dapat dirasakan dengan cara yang sama terhadap nilai itu sendiri, dengan demikian nilai yang lebih tinggi tersebut dipahami dengan tindakan mendahulukan, mengunggulkan, atau mengutamakan dengan tindakan meremehkan terhadap nilai yang lebih rendah. Tingkatan suatu nilai merupakan hal yang keberadaannya memang sudah demikian berdasarkan hakikatnya, dan dapat dirasakan melalui preferensi.

Perasaan cinta dan benci adalah tindakan yang mempengaruhi preferensi. Kita cenderung tertarik dengan yang lebih besar atau nilai positif, dan cenderung menjauh atau menolak nilai negatif. Hal tersebut hadir dalam setiap pengalaman pada setiap peringkat nilainilai. Tindakan preferensi berbeda dengan tindakan memilih, tindakan preferensi adalah tindakan yang mengutamakan pemilihan atau keinginan tanpa menunjukkan adanya kecenderungan, sedangkan tindakan memilih adalah tindakan kecenderungan yang telah mencakup pengetahuan tentang nilai. (Max Scheler, 1973: 74)

Itu Artinya, tindakan preferensi bukanlah sikap memilih atau keinginan yang terintervensi oleh pengetahuan tentang nilai, dan merupakan tindakan memilih dan keinginan yang independen.

Sikap memilih atau pilihan terkait pada nilai sebuah objek yang bersifat empiris, sedangkan preferensi terkait dengan nilai yang bersifat a priori, meskipun nilai tidak memiliki kejelasan sebelum preferensi. Hal tersebut tidaklah berarti bahwa keunggulan suatu nilai disebabkan oleh suatu kenyataan bahwa nilai tersebut lebih diutamakan. Keunggulan nilai yang dialami oleh manusia bersifat empiris, sedangkan dalam hierarki nilai adalah sesuatu yang melekat dalam setiap inti nilai. Hal ini berarti bahwa hierarki nilai tidak berubah dan bergantung pada pengalaman manusia. Walau tidak berubah dan bergantung pada pengalaman manusia, susunan hierarki nilai tidak berarti dapat dideduksikan secara logis, sebab hal tersebut merupakan kenyataan intuitif dari preferensi yang tidak dapat dideduksikan pula.

Nilai pada dasarnya berada dalam susunan hierarki, yang terhubung secara koheren melalui posisi yang lebih tinggi dengan yang lebih rendah, dan hubungan ini hanya dapat dipahami dalam tindakan preferensi, sehingga nilai pun memiliki landasan pada tindakan tersebut. Susunan hierarki nilai tidak pernah dapat dideduksikan secara logis, hal ini dapat dilihat dari penjelasan Scheler yang membagi hierarki nilai menjadi empat tingkat, yaitu:

Nilai kesenangan: merupakan tingkat terendah yang berkaitan dengan fungsi dari perasaan inderawi, yaitu kepuasan, kemalangan, kebahagiaan, dan seterusnya. Rumusan tentang kesenangan yang lebih disukai ketimbang kemalangan tidaklah ditentukan oleh pengamatan empiris atau induksi, tetapi ditentukan oleh pengalaman yang mendahului dan tidak dilandasi oleh pengamatan induksiempiris. Sehingga, secara a priori bahwa setiap orang akan memilih hal yang menyenangkan daripada kemalangan.

Nilai vitalitas: terdiri dari nilainilai kehidupan yang berupa kesejahteraan pada umumnya, dan nilai ini memiliki kedudukan yang lebih tinggi dibandingkan dengan nilai kesenangan. Nilai ini mengasosiasikan perasaan yang tidak bergantung pada sesuatu, serta tidak dapat direduksikan.

Nilai spiritual: merupakan nilai yang tidak terikat oleh fisik dan lingkungan alam semesta. Kedudukan nilai ini lebih tinggi dari kedua nilai 
sebelumnya, dan seseorang wajib mengorbankan nilai vitalitas demi nilai ini. Nilai ini memiliki jenis utama, yakni nilai estetis, nilai benar-salah (terkait pada persoalan norma dan hukum), dan nilai pengetahuan murni (merupakan corak usaha filsafat selama ini). Selain tiga nilai utama tersebut, nilai spiritual memiliki nilai-nilai turunan yang lain, yakni meliputi; nilai budaya, nilai keindahan, nilai seni.

Nilai kesucian dan keprofanan: merupakan nilai dengan kedudukan tertinggi, dan hanya tampak oleh manusia dalam bentuk objek absolut. Nilai ini tidak terikat oleh status personal seseorang, karena nilai ini merupakan nilai yang mewakili sebuah cinta khusus yang secara hakiki terarah pada personalitas. Artinya, tingkatan nilai ini terdiri dari nilai-nilai pribadi, yang memiliki turunan berupa ritual kepercayaan terhadap pribadi yang dipuja.

Bagi Scheler, hubungan hierarki nilai tersebut, dengan sifat a priori-nya, mendahului keterikatan yang ada, hal ini dapat diterapkan dalam nilai yang terwujud melalui objek. Keempat tingkatan nilai tersebut, tidak terdapat nilai moral, karena Scheler menjelaskan nilai moral sebagai nilai yang berada dalam dimensi yang berbeda. Nilai moral ditemukan dalam perwujudan nilai-nilai non-moral, dan melekat pada tindakan yang mewujudkan nilai lainnya melalui aturan tertentu yang benar.

\section{METODE PENELITIAN}

Penelitian ini merupakan penelitian kepustakaan. Dalam proses penelitian ini menggunakan metode interpretasi dengan diupayakan 3 hal, yakni; Bahan dan materi penelitian diperoleh melalui penelusuran pustaka yang terkait dengan slametan masyarakat Jawa dan buku yang berkaitan dengan pemikiran Max Scheler. Analisis data dilakukan dengan lima cara berdasarkan analisis interpretasi, yaitu: deskripsi, memberikan gambaran tentang prosesi dari slametan masyarakat Jawa dan teori fenomenologi nilai Max Scheler; koherensi Intern: analisis teori fenomenologi nilai Max Scheler terhadap slametan dalam masyarakat Jawa sesuai dengan aspek dalam struktur yang logis dan sistematis; Interpretasi: analisis datadata pustaka, terkait slametan masyarakat Yogyakarta berdasarkan pendekatan fenomenologi nilai dari objek formal penelitian ini; heuristika: peneliti memahami data secara komprehensif sehingga didapatkan pemahaman yang tepat; dan refleksi Kritis: membangun suasana kontemplatif dan masukan yang progresif sehingga dapat merekonstruksi slametan masyarakat Jawa secara mendalam.

\section{HASIL DAN PEMBAHASAN}

Mengacu pada fenomenologi nilai

Max Scheler, Slametan dalam masyarakat Yogyakarta adalah fenomena yang sarat makna dan nilai-nilai. Nilainilai yang terdapat di dalam slametan masyarakat Yogyakarta adalah a priori material. Nilai-nilai tersebut sudah ada sebelum slametan dilakukan, karena nilai itu tidak bergantung pada pembawanya. Nilai-nilai tersebut seperti nilai kenikmatan, nilai vitalitas, dan nilai kerohanian dan nilai kesucian pada dasarnya nilai kesucian sudah ada dan tetap ada meskipun slametan tidak dijalankan. Serta nilai-nilai yang terdapat dalam slametan masyarakat Yogyakarta bersifat material yakni "berisi", nilai-nilai tersebut berisi makna dan tujuan diadakannya slametan tersebut.

Makna dan tujuan di dalam slametan masyarakat Yogyakarta tergambar pada simbol-simbol yang dituangkan melalui media makanan dalam sesaji yang digunakan. Pada setiap simbol yang digunakan selalu memiliki 
makna yang berbeda satu sama lain, namun memiliki keterkaitan yang pada akhirnya selalu mengarah dan berhubungan dengan eksistensi Tuhan.

Fenomenologi menurut Max Scheler adalah fenomena yang menekankan pada pengalaman intuitif. Dalam konteks slametan, pengalaman intuitif manusia akan keberadaan kekuatankekuatan tersebut dimulai dari merasakannya bahwa ada kekuatan yang berada di luar dirinya dan ikut mengendalikan setiap aspek kehidupannya. Kekhawatiran membuat mereka mencari jawaban dengan menciptakan ide-ide yang mereka sebut dengan Tuhan/Allah/Illahi dan lainnya. Yang pada akhirnya orientasi atas kekuatan tersebut membawa mereka pada sebuah pengalaman intuitif ataupun pengalaman religius.

Ritual sendiri adalah fenomena yang menampakkan diri, dan slametan yang merupakan salah satu jenis ritual yang juga merupakan fenomena masyarakat Yogyakarta dalam memenuhi kebutuhan nilai dalam hidupnya. Inti dari fenomenologi Scheler adalah penghayatan akan suatu pengalaman, dan slametan sebagai sebuah ritual merupakan refleksi atas pengalaman intuitif ataupun pengalaman religius manusia yang muncul karena keterbatasan manusia dan kepercayaannya akan adanya sesuatu yang berada diluar dirinya, mengitarinya dan ikut mengatur kehidupannya.

Slametan masyarakat Yogyakarta sebagai fenomena yang menekankan pada pengalaman intuitif ini, umumnya didapatkan tanpa melalui proses penalaran tertentu, serta bersifat personal. Seorang pelaku mencoba memahami dengan baik sebuah suatu fenomena yang hadir di sekelilingnya sebagaimana adanya, namun seperti telah dikatakan bahwa pengalaman ini bersifat personal jadi pengalaman ini akan berbeda-beda pada setiap individu yang mengalaminya. Hal tersebut dikarenakan suatu pengalaman intuitif yang muncul dalam diri personal belum tentu muncul dan ada dalam diri orang lain. Tetapi dari pengalaman intuitif yang bersifat personal itu, pada akhirnya terus dipelihara dinyatakan dalam slametan.

Seperti yang dinyatakan Max Scheler bahwa fenomenologi berusaha untuk menangkap esensi, yang secara langsung dapat ditangkap oleh intuisi sebagai sesuatu yang bersifat a priori. Oleh karena itu masyarakat Yogyakarta melalui pengalaman intuitif dalam hubungannya dengan slametan yang memberi persembahan berupa sesaji merupakan pengalaman a priori, dimana esensi dari slametan tersebut mendahului pengalaman ketika melaksanakan kegiatan tersebut. Misalnya slametan kematian, dalam diri mereka sudah ada konsep bahwa jika mereka tidak melakukan slametan bagi sanak saudara mereka yang mengalami kematian, maka orang yang mengalami kematian tersebut tidak mendapatkan tempat layak di sisi Tuhan. Hal tersebut menunjukkan bahwa sudah ada konsep dalam pikiran mereka tanpa harus mengalaminya terlebih dahulu. Jadi hakikat mereka mengadakan slametan bagi orang yang sudah mengalami kematian adalah kepercayaan pada Tuhan, dan memohon agar orang yang mengalami kematian mendapatkan tempat yang layak disisi Tuhan.

Menurut Max Scheler, nilai itu bersifat a priori dan material, a priori karena nilai mendahului segala pengalaman, material bukan dalam arti kata materi melainkan "berisi". Berisi di sini bisa ditafsirkan tujuan dan makna. Terlepas dari tujuan dan maknanya, berdasarkan pemahaman fenomenologinya, Max Scheler membagi nilai menjadi empat struktur nilai yang mandiri dan jelas berbeda satu dengan yang lainnya dan disusun dalam sebuah hierarki.. Nilai 
yang berada pada tingkatan paling rendah adalah nilai kenikmatan yang menyangkut "yang enak" atau "yang tidak enak" yang merupakan tingkatan paling rendah dalam hierarki nilai Scheler karena nilai ini memiliki relativitas yang tinggi. Tingkatan yang berkaitan dengan fungsi dari perasaan inderawi ini terdapat dalam slametan masyarakat Yogyakarta sebagai nilai yang paling terlihat jelas, nilai kenikmatan ini terletak pada hubungan dengan perasaan perseptif seperti pada saat makan-makan "enak". Simbol-simbol dalam sesaji yang berupa aneka makanan yang berisi aneka tumpeng, kue, buah-buahan yang disajikan dan dinikmati bersama-sama. Mereka yang ikut berpatisipasi dalam kegiatan tersebut mendapatkan kesenangan karena dapat berkumpul bersamasama untuk menikmati makanan yang disajikan. Hal tersebut dapat dikategorikan dalam nilai kenikmatan atau kesenangan. Nilai kenikmatan lain karena berhubungan dengan perasaan nikmat dan nilai guna yang ada dalam ritual sesajen ini adalah para pelakunya yang mendapatkan kesenangan jika dapat melakukan slametan tersebut dengan baik dan lancar. Seperti yang dikatakan oleh Max Scheler bahwa nilai kenikmatan atau kesenangan juga mencakup nilai-nilai teknis dan nilai-nilai pada simbol.

Nilai yang berada di atas nilai kenikmatan adalah nilai vitalitas, yang mencakup nilai-nilai dalam kehidupan yang merupakan tingkatan lebih tinggi dari struktur nilai kenikmatan. Nilai ini mengasosiasikan perasaan yang tidak bergantung pada sesuatu, dan tidak dapat direduksikan. Nilai ini berupa nilai luhur dan hina, halus dan kasar, serta mencakup nilai kesejahteraan. Dalam slametan di masyarakat Jawa Yogyakarta, hal-hal seperti di atas terdapat dalam setiap latar belakang dilakukannya slametan ini. Slametan, latar belakang dilakukannya adalah untuk mencapai keadaan slamet, selain itu slametan dilakukan untuk mensyukuri anugerah yang diberikan oleh Tuhan seperti dalam slametan untuk menandai peristiwa kelahiran ataupun pernikahan. Tidak hanya itu dalam slametan ini juga merupakan bentuk penghormatan bagi para leluhur. Dalam slametan, kesejateraan merupakan nilai yang ingin diwujudkan bagi si pelaku. Nilai lanjutan berupa nilai keselamatan nilai tersebut ditemukan dalam slametan, karena slametan sendiri memiliki arti selamat yang merupakan harapan agar pelaku maupun orang yang dislameti mendapat keselamatan.

Nilai yang ketiga adalah nilai kerohanian, banyak orang atau individu menghiraukan nilai vitalitas untuk mencapai nilai ini. Karena nilai ini berada di atas tingkatan nilai vitalitas. Nilai yang tidak memiliki keterikatan dengan fisik dan lingkungan alam semesta ini memiliki tiga jenis nilai yang utama, nilai estetis, nilai benar-salah, dan nilai pengetahuan murni. Namun selain itu, seperti yang sedikit disinggung di bab sebelumnya, struktur nilai ini memiliki turunan nilai yang lain seperti nilai budaya, seni, dan lainnya. Tiga nilai utama yaitu estetis, benar-salah, dan nilai pengetahuan murni tertuang dalam sesajen yang disajikan oleh ritual tertentu seperti yang telah dijelaskan sebelumnya. Nilai estetik adalah nilai yang berkaitan dengan "yang indah" dan "yang jelek". Pada selametan, aspek nilai ini dapat dilihat simbol yang disajikan yang pada bab 2 disebut dengan sesaji yang menghasilkan keteraturan dan keharmonisan. Misalnya dalam tata letak atau pengaturan konsep penataan tumpeng dan simbol yang lain, tumpeng dibentuk mengerucut dengan sempurna sehingga terlihat indah, dan sebaliknya jika tidak sesuai maka "yang jelek" muncul. Nilai benar-salah, nilai ini merupakan dasar bagi gagasan tatanan hukum objektif yang bebas dari gagasan 
undang-undang dan gagasan negara serta dari gagasan komunitas hidup yang mendasarinya. Dari tataran yang disampaikan oleh Scheler tersebut, terhadap slametan pada keempat ritual sesajen tersebut, dapat dilihat aspek nilai spiritual tertuang dalam tata sikap setiap elemen pelaku ritual serta inti dari slametan yakni berdoa kepada Tuhan. Nilai yang ketiga adalah nilai pengetahuan murni yang direalisasikan oleh filsafat. Namun penulis belum dapat menemukan aspek nilai ini dalam selametan, Hanya saja didapat inti yang merupakan pembenaran esensinya, yakni suatu ucapan rasa syukur, sebuah penghormatan, dan keyakinan akan "kekuatan" yang berada di luar dirinya dan ikut mengendalikan tuas kehidupan mereka, Tuhan.

Nilai yang mempunyai tingkat relativisme paling rendah adalah nilai kesucian dan keprofanan. Nilai kesucian merupakan nilai yang paling pokok, yang merupakan esensi dari slametan itu sendiri. Namun di dalam slametan tidak terdapat nilai keprofanan yang dimaksud oleh Max Scheler. Nilai kesucian merupakan nilai dengan tingkat relativitas yang paling rendah atau tidak ada sama sekali yang artinya, nilai ini adalah nilai yang absolut, dan bagi Scheler nilai absolut yang dimaksud adalah emosi murni seperti tindakan preferensi dan cinta, misalnya perasaan kebahagiaan dan keputusasaan yang sama sekali tidak berkaitan dan bergantung dengan keberuntungan dan kemalangan. Absolut yang dimaksud di sini adalah tidak terikatnya emosi pada perasaan inderawi dan inti kehidupan. Pada taraf ini pula Scheler menyebutkan nilai kesucian sebagai bagian dari nilai yang bersifat absolut. Dalam slametan masyarakat Yogyakarta, nilai kesucian terletak pada kepercayaan kepada Tuhan yang lebih diutamakan daripada sikap yang meluhurkan yang lain, maka
"Tuhan" lah yang menjadi objek mutlak dalam slametan tersebut. Dalam slametan terlihat sebuah kepasrahan dari para pelaku ritual kepada Tuhan, yang merupakan objek mutlak. Namun pada dasarnya, nilai kesucian berlaku untuk masyarakat umum, walaupun bukan masyarakat Yogyakarta jika terlibat langsung dalam slametan maka secara tidak langsung juga akan menghayati nilai ini. Nilai kesucian dalam slametan juga dapat dikembalikan pada pandangan hidup masyarakat Jawa untuk melakukan slametan, yakni sangkan paraning dumadi. Sangkan Paran adalah penggabaran sebuah hakikat asal dan tujuan dalam Ketuhanan. Sangkan paraning dumadi merujuk pada Yang Mutlak, sebagai tempat asal dan kembalinya manusia. Penulis pun menafsirkan nilai ini juga berhubungan dengan "kekhidmatan", ataupun pemujaan. Jadi, pada dasarnya nilai kesucian dalam semua jenis slametan, sangat terlihat jelas dari hal yang mendasari seluruh kegiatan ritual sesaji tersebut, yakni usaha untuk mendekatkan diri kepada Tuhan yang dipercaya, dengan menggunakan perantaraperantara yang dikorbankan dalam kekayaan alam yang disebut sesajen karena Scheler juga mengungkapkan bahwa, lanjutan dari nilai kesucian ini dapat berupa benda-benda suci atau bentuk peribadatan dan sakramensakramen, seperti halnya doa-doa yang dipanjatkan atau benda-benda yang digunakan sebagai perantara.

Nilai-nilai tersebut juga terdapat di dalam makna dari simbol-simbol yang dihadirkan dalam sesaji. Simbol-simbol dalam sesaji slametan yang berupa makanan ataupun hasil bumi, memiliki makna yang menggambarkan suatu hubungan individu dengan sesamanya, individu dengan alam atau lingkungannya, serta hubungan individu dengan Tuhan-nya. Hal tersebut tersirat 
dalam simbol-simbol sesaji slametan misalnya pada kue apem, Apem berasal dari bahasa Arab yaitu Afu'un, makna dari simbol ini adalah ampunan, sehingga orang yang memakan apem tersebut mengharapkan ampunan oleh Yang Maha Kuasa. Selain itu, kue apem dalam upacara ini memiliki makna-makna yang mendalam terkait hubungan manusia dengan sesamanya, yakni saling berbagi, selalu bersyukur, dan berkah. Serta tumpeng, merupakan simbol dalam sesajen yang selalu ada dalam slametan besar. Tumpeng memiliki bentuk kerucut ke atas mengandung makna bahwa kita sebagai manusia diwajibkan agar selalu ingat pada Yang Maha Kuasa, manunggaling kawula lan Gusti, yang menciptakan manusia dan alam semesta beserta isinya.

Dari contoh tersebut, penulis menemukan bahwa sesaji sebagai simbolsimbol yang menyembunyikan makna dan nilai-nilai. Jika mengacu pada konsep nilai Max Scheler, dapat diinterpretasikan bahwa dalam makna-makna simbol tersebut telah membawa nilai-nilai, mulai dari nilai kenikmatan sampai dengan nilai kesucian dan keprofanan. Seperti dalam kue apem, Apem yang berasal dari bahasa Arab yaitu $A f u$ 'un, makna dari simbol ini adalah ampunan, sehingga orang yang memakan apem tersebut mengharapkan ampunan oleh Yang Maha Kuasa. Jika dilihat dari makna tersebut, dalam makna kue apem ini terdapat nilai kesucian. Mengharapkan ampunan dari Yang Maha Kuasa merupakan turunan dari suatu sikap yang menjawab nilai-nilai yang kudus yakni percaya akan adanya Tuhan atau sesuatu kekuatan yang berada diluar dirinya. Begitu juga dengan tumpeng, dari makna tumpeng secara umum, bahwa sebagai manusia diwajibkan agar selalu ingat pada Yang Maha Kuasa, manunggaling kawula lan Gusti. Nilai kesucian dalam makna simbol ini sudah sangat jelas, bahwa berhubungan dengan kepercayaan terhadap Tuhan. Hal tersebut merupakan suatu kepercayaan, keimanan terhadap Tuhan yang dapat kita sebut dengan Yang Mutlak, yang dianggap memiliki kekuatan untuk ikut mengatur segala siklus kehidupan manusia, dan alam semesta.

\section{SIMPULAN}

Slametan yang dijalankan oleh masyarakat Yogyakarta pada dasarnya merupakan sebuah tradisi yang dilakukan secara turun-temurun. Slametan masyarakat Yogyakarta merupakan sebuah bentuk penghayatan atas proses kehidupan manusia yang dimulai dari kelahiran hingga kematian. Dalam kaca mata fenomenologi Max Scheler, slametan yang ada di masyarakat Yogyakarta merupakan sebuah fenomena atau gejala yang menekankan pada pengalaman intuitif terhadap sesuatu yang ada, karena slametan, merupakan usaha manusia untuk menemukan eksistensi dari sebuah realitas. Slametan merupakan fenomena atau gejala yang hadir sebagai penanda adanya sesuatu dibalik ritual itu sendiri. Slametan merupakan bentuk penghayatan akan suatu pengalaman, dan slametan sebagai sebuah ritual merupakan refleksi atas pengalaman religius manusia yang muncul karena keterbatasan manusia dan kepercayaannya akan adanya sesuatu yang berada diluar dirinya, mengitarinya dan ikut mengatur kehidupannya. Jadi, slametan yang ada di masyarakat yogyakarta adalah suatu tindakan lansung yang merupakan refleksi atas suatu pengalaman intuitif akan kesadaran objek.

Fenomenologi Max Scheler berusaha untuk menangkap esensi, yang secara langsung dapat ditangkap oleh intuisi sebagai sesuatu yang bersifat $a$ priori, oleh karena itu masyarakat Yogyakarta lewat pengalaman intuitif 
masyarakat Yogyakarta dalam hubungannya dengan slametan yang memberi persembahan berupa sesajen merupakan pengalaman a priori, karena esensi dari slametan tersebut mendahului pengalaman melaksanakan kegiatan tersebut.

Dalam fenomenologi Max Scheler, nilai menjadi ciri khusus dalam pendekantannya. Nilai yang di maksud oleh Scheler adalah nilai yang bersifat $a$ priori dan material, a priori karena nilai itu ada mendahului pengalaman, dan material bukan dalam arti materi melainkan ada isinya, isi itu bisa berarti makna dan tujuan. Dalam konteks slametan yang ada dalam masyarakat Yogyakarta, nilai yang ada bersifat $a$ priori, nilai itu sudah ada terlebih dahulu tanpa harus mengalaminya. Misalnya nilai kesucian dalam sebuah ritual, nilai itu sudah ada lebih dulu sebelum pelaku ritual itu menjalankan ritualnya. Berdasarkan pemahaman fenomenologinya, Max scheler membagi nilai ke dalam empat struktur nilai, yakni nilai kenikmatan, nilai vitalitas, nilai rohani, dan nilai kesucian dan keprofanan. Empat struktur nilai itu jika digunakan untuk mengkaji nilai yang ada dalam slametan masyarakat Yogyakarta, akan disimpulkan seperti ini; (1) nilai kenikmatan dalam slametan terletak pada yang berhubungan dengan perasaan perseptif seperti pada saat makan-makan "enak". Simbol-simbol dalam sesajen yang berupa aneka makanan yang berisi aneka tumpeng, kue, buah-buahan yang disajikan dan dinikmati bersama-sama. Seperti yang dikatakan oleh Max Scheler bahwa nilai kenikmatan atau kesenangan juga mencakup nilai-nilai teknis dan nilai-nilai pada simbol. (2) Nilai vitalitas, terletak dalam setiap latar belakang dilakukannya slametan ini. Selametan, latar belakang dilakukannya adalah untuk mencapai keadaan slamet, selain itu slametan dilakukan untuk mensyukuri anugerah yang diberikan oleh Tuhan seperti dalam slametan untuk menandai peristiwa penting. Nilai lanjutannya adalah nilai keselamatan nilai tersebut ditemukan dalam slametan, karena slametan sendiri memiliki arti selamat yang merupakan sebuah harapan. (3) nilai rohani, memiliki tiga jenis nilai yang utama, nilai estetis, nilai benar-salah, dan nilai pengetahuan murni. Nilai estetik dilihat dari simbol yang disajikan yang menghasilkan keteraturan dan keharmonisan. Nilai benar-salah, tertuang dalam tata sikap setiap elemen pelaku ritual serta inti dari slametan yakni berdoa kepada Tuhan. Nilai yang ketiga adalah nilai pengetahuan murni yang direalisasikan oleh filsafat, didapat dari inti pembenaran esensinya, yakni suatu ucapan rasa syukur, sebuah penghormatan, dan keyakinan. (4) Nilai kesucian yang merupakan nilai paling tinggi dalam strukturan nilai Max scheler. Dalam slametan, nilai kesucian dalam terletak pada kepercayaan kepada Tuhan yang lebih diutamakan daripada sikap yang meluhurkan yang lain, maka "Tuhan" lah yang menjadi objek mutlak dalam slametan tersebut.

Kesimpulan terakhir yang dapat ditarik untuk menjawab rumusan masalah yang ketiga adalah bahwa sesaji sebagai simbol-simbol yang menyembunyikan makna dan nilai-nilai. Makna-makna yang ada di dalam simbol sesajen masyarakat Yogyakarta memiliki nilainilai, mulai dari nilai kenikmatan sampai dengan nilai kesucian dan keprofanan. Hal tersebut dapat dilihat dari makna tumpeng secara keseluruhan, yang mengacu pada manunggaling kawula lan Gusti, yang merupakan sebuah kepercayaan kepada Yang Mutlak.

Setelah dilakukan analisis mendalam terkait dengan slametan masyarakat Yogyakarta, tidak semua nilai yang dijabarkan Max Scheler dalam hierarki nilainya dapat ditemukan dalam slametan masyarakat Yogyakarta. Nilai 
keprofanan yang disandingkan oleh Max Scheler dengan nilai kesucian tidak ditemukan oleh penulis dalam slametan masyarakat Yogyakarta. Karena menurut penulis, nilai kesucian merupakan esensi yang paling penting dalam slametan itu sendiri, sehingga mengeliminir nilai keprofanan. Oleh sebab itu, hendaknya masyarakat Yogyakarta tetap mempertahankan nilai-nilai kesucian dalam slametan sebagai upaya melestarikan kebudayaan daerah.

Selain itu, konsep nilai Max Scheler ini jika di lihat dari sudut pandang masyarakat umum, slametan akan memiliki makna ganda bagi si penyelenggara slametan dan si penikmat slametan. Misalnya, nilai kesucian yang menjadi landasan penting bagi slametan akan seolah-olah terlihat hanya pada penyelenggaranya saja, tidak pada penikmatnya atau tamu yang hadir. Oleh karena itu menurut penulis, nilai kesucian dalam slametan akan dapat dihayati oleh si penyelenggara maupun penikmat jika mereka memiliki latar belakang yang sama, misalnya sesama masyarakat Yogyakarta.

\section{DAFTAR PUSTAKA}

Alex, S. (2013). Buku Filsafat Komunikasi, tradisi dan metode fenomenologi. Bandung: Rosda Karya.

Bell, C. (1992). Ritual Theory, Ritual Practice. New York: Oxford University Press.

Bertens, K. (1983). Filsafat Barat Abad $X X$ : Inggris-Jerman, Seri Filsafat Atmajaya. Jakarta: Gramedia.

Bratawidjaja, W. (1988). Upacara Perkawinan Adat Jawa. Jakarta: Pustaka Sinar Harapan.

Mengungkap dan Mengenal
Budaya Jawa. Jakarta: PT Pradnya Paramita.

Cliffor, G. (2013). Agama Jawa. Jakarta: Komunitas Bambu.

Pals, D. L. (2012). Seven Theories of Religion, diterjemahkan oleh M. Syukri. Yogyakarta: IRCiSoD.

Dillistone, F. W. (2002). The Power of Symbol Diterjemahkan oleh: Widyamartaya. Yogyakarta: Kanisius.

Ewing, A.C. (2003). The Fundamental Question of Philosophy, diterjemahkan oleh Uzair Fauzan. Yogyakarta: Pustaka Pelajar.

Frondizi, R. (2009). Pengantar Filsafat Nilai. Yogyakarta: Pustaka Pelajar.

Harun, H. (1980). Sari Sejarah Filsafat Barat Pra Modern. Yogyakarta: Kanisius.

Koentjoroningrat. (1994). Pengantar Antropologi. Jakarta: Aksara Baru.

Koentjaraningrat dan antropologi di Indonesia, Obor: Jakarta.

Luther, A. R. (1970). Scheler's Interpretation of Being as Loving. Philosophy today XIV (Fall).

Suseno, F. M. (1997). 13 Tokoh Etika Abad ke-29. Yogyakarta: Kanisius.

(2000). 12 Tokoh Etika Abad ke-20. Yogyakarta: Kanisius.

\section{(2006). Etika} Abad Kedua Puluh. Yogyakarta: Kanisius.

Gauthama, M. P. (2003). Budaya Jawa dan Masyarakat Modern. Jakarta: BPPT. 
Meyer, H. (1987). Max Scheler Understanding of The Phenomenological Method dalam International Studies in Philosophy Vol XIX. New York: Scholar Press.

Michael, K. (2006). Agama-Agama Dunia. Diterjemahkan FA, Soeprapto. Yogyakarta: Kanisius.

Moran, D. (2000). Introduction to Phenomenology. London: Routledge.

Owens, T. J. (1968). Scheler's Emotive Ethics. Philosophy Today XII (Spring).

Peursen, V. (1985). Strategi Kebudayaan. Yogyakarta: Kanisius.

Russel, B. (2007). Sejarah Filsafat Barat, diterjemahkan oleh Jatmiko, Prihantoro. Yogyakarta: Pustaka Pelajar.

Sandmeyer, B. (2009). Husserl's Constitutive Phenomenology. New York: Routledge.

Scheler, M. (1954). The Nature of Sympathy, diterjemahkan oleh Peter Heath, London: Routledge \& Kegan Paul Ltd.1973.

, Formalism in Ethics and Non-Formal Ethics of Values. Amerika: Northwestern University Pers.

, (1994). Ressentiment, diterjemahkan oleh Lewis B Coser dan William W Holdheim. Milwaukee, Wisconsin, AS: Merquerte University Press.

Slamet, S. (1983). Sedikit tentang Strategi Kebudayaan. Yogyakarta: Obor.

Smith, D. W. (2007). Husserl. New York: Routledge.
Solomon, R. C., dan Higgins, K. (2000). Sejarah Filsafat Barat. Yogyakarta: Bentang Pustaka.

Tashadi, dkk. 1992. Upacara Tradisional Saparan Daerah Gamping dan wonolelo Daerah Istimewa Yogyakarta. Yogyakarta: Depdikbud.

Titus, H., Smith, M., Nolan, R. (1979). Living Issue In Philosophy, diterjemahkan oleh Rasjidi. Jakarta: PT Midas Surya Grafindo.

Wahana, P. (2004). Nilai Etika Aksiologi Max Scheler. Yogyakarta: Kanisius.

Wahyana, G. (2010) Sajen dan Ritual Orang Jawa. Yogyakarta: Narasi.

Zeitlin, I. (1995). Memahami Kembali Sosiologi. Yogyakarta: Gadjah Mada university Press.

\section{Sumber Internet:}

Max Scheler, Online, Tersedia di http://www.maxscheler.com/sche ler1.shtml\#1-BioData, Diakses tanggal 5 Maret 2014.

Fenomenologi Max Scheler, Online, Tersedia di http://syaharbanu.blogspot.com/2 012/04/max-scheler-wanita fenomonologi-dan.html, Diakses 6 Maret 2014

Max Scheler, Online, tersedia di http://plato.stanford.edu/entries/s cheler/, Diakses tanggal 1 Juli 2014.

Budaya Sesajen, On-line, Tersedia dihttp://aliwafapuncak.blogspot.com /p/budaya

sesajen.html, Diakses 15 Februari 2014. 
Wahyudi, "Islam dan Nilai-Nilai Budaya Jawa", Makalah Tugas, (Kediri, Agustus 2011), h. 12. 